\title{
A novel sheet topology in the structure of kamitugaite, $\operatorname{PbAl}\left[\left(\mathrm{UO}_{2}\right)_{5}\left(\mathrm{PO}_{4}\right)_{2.38}\left(\mathrm{AsO}_{4}\right)_{0.62} \mathrm{O}_{2}(\mathrm{OH})_{2}\right]\left(\mathrm{H}_{2} \mathrm{O}\right)_{11.5}$
}

\author{
Jakub PLÁŠIL
}

Institute of Physics, Academy of Sciences of the Czech Republic v.v.i, Na Slovance 2, 182 21, Prague 8, Czech Republic; plasil@fzu.cz

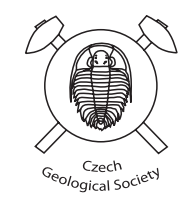

Kamitugaite is a rare supergene uranyl phosphate of aluminum and lead occurring at the Kobokobo pegmatite in the Sud-Kivu Province, Democratic Republic of Congo; its structure has remained unknown until now. Based on single-crystal X-ray diffraction data carried out on the type specimen of kamitugaite (no. 13986, Royal Museum for Central Africa, Tervuren), it is triclinic, space group $P-1$, with $a=9.0296(8), b=10.9557(8), c=15.8249(15) \AA, \alpha=89.585(7)^{\circ}$, $\beta=85.349(8)^{\circ}, \gamma=84.251(7)^{\circ}, V=1552.5(2) \AA 3$ and $Z=2$. The structure was refined from diffraction data to $R=0.1074$ for 2697 unique observed reflections. The structure of kamitugaite is based upon infinite sheets of uranyl and phosphate polyhedra, stacked perpendicular to $\mathbf{c}$; these sheets result from edge-sharing of $\mathrm{UO}_{7}$ and $\mathrm{UO}_{8}$ bipyramids, forming chains approximately parallel to $b$, which are linked by $(\mathrm{P}, \mathrm{As}) \mathrm{O}_{4}$ tetrahedra. Such a sheet has not been observed in minerals or synthetic compounds and is related to the phosphuranylite topology; the ring symbol is $6^{1} 5^{4} 4^{3} 3^{4}$. There are two distinct interlayer complexes in kamitugaite: one involving $\mathrm{Pb}^{2+}$ and $\mathrm{H}_{2} \mathrm{O}$ groups and another involving octahedrally coordinated $\mathrm{Al}^{3+}$ and isolated $\mathrm{H}_{2} \mathrm{O}$ groups. Adjacent sheets are linked a) through the $\mathrm{Pb}^{2+}-\mathrm{O}$ and $\mathrm{H}$-bonds, and b) via $\mathrm{H}$-bonds only in case of the interlayer with $\mathrm{Al}$, the bonding differences being largely attributable to the very different stereochemistry of $\mathrm{Pb}^{2+}$ compared to $\mathrm{Al}^{3+}$. The unique combination of these two elements is probably a key reason for the scarcity of kamitugaite.

Keywords: kamitugaite, uranyl phosphate, crystal structure, topology

Received: 6 October, 2017; accepted: 8 December, 2017; handling editor: J. Sejkora

The online version of this article (doi: 10.3190/jgeosci.246) contains supplementary electronic material.

\section{Introduction}

Uranyl phosphates and arsenates are environmentally important minerals resulting from hydration-oxidation weathering of primary $U$ minerals, mainly uraninite. They are common constituents of the oxidized parts of U deposits worldwide (Finch and Murakami 1999; Krivovichev and Plášil 2013). Generally, due to their low solubility products, they often occur in the very leached parts of the deposit, i.e., on outcrops, thus being an important control of U mobility (see, e.g., Göb et al. 2013).

The Kobokobo pegmatite in the Sud-Kivu Province (western Democratic Republic of Congo, Africa) (Safiannikoff and Van Wambeke 1967; Van Wambeke 1987) is one of the most interesting mineralogical localities in the World, largely due to occurrences of rare uranium and thorium phosphates within the U-bearing quartzalbite-muscovite pegmatite. This pegmatite is a typelocality for twelve actinide-bearing phosphates, most of which contain Al (Tab. 1). Although several crystalstructure studies have been conducted, structures of many of the Kobokobo type minerals remain unknown. Results of a study on the particularly interesting structure of kamitugaite are presented in this paper.

\section{Sample}

The crystal of kamitugaite investigated by single-crystal $\mathrm{X}$-ray diffraction originates from the type specimen of this mineral preserved in the collection of the Royal Museum for Central Africa in Tervuren (Belgium); specimen $\mathrm{n}^{\circ}$ RGM13986. It contains yellow to amber prismatic kamitugaite (Fig. 1) along with yellow lathlike phuralumite, yellow micaceous mundite, yellow prismatic upalite and metatorbernite.

\section{Single-crystal X-ray crystallography}

\subsection{Experimental}

A prismatic crystal of kamitugaite, with dimensions $0.054 \times 0.014 \times 0.008 \mathrm{~mm}$, was selected for the diffraction experiment on a Rigaku SuperNova diffractometer equipped with Atlas S2 CCD detector and mirror-monochromatized $\mathrm{Mo} K_{\alpha}$ radiation provided by the microfocus $\mathrm{X}$-ray tube. A sphere of three-dimensional intensity data was collected using frame widths of $1.0^{\circ}$ in $\omega$, with 400 seconds counting per frame. Diffraction data were processed using the CrysAlis software (Rigaku 


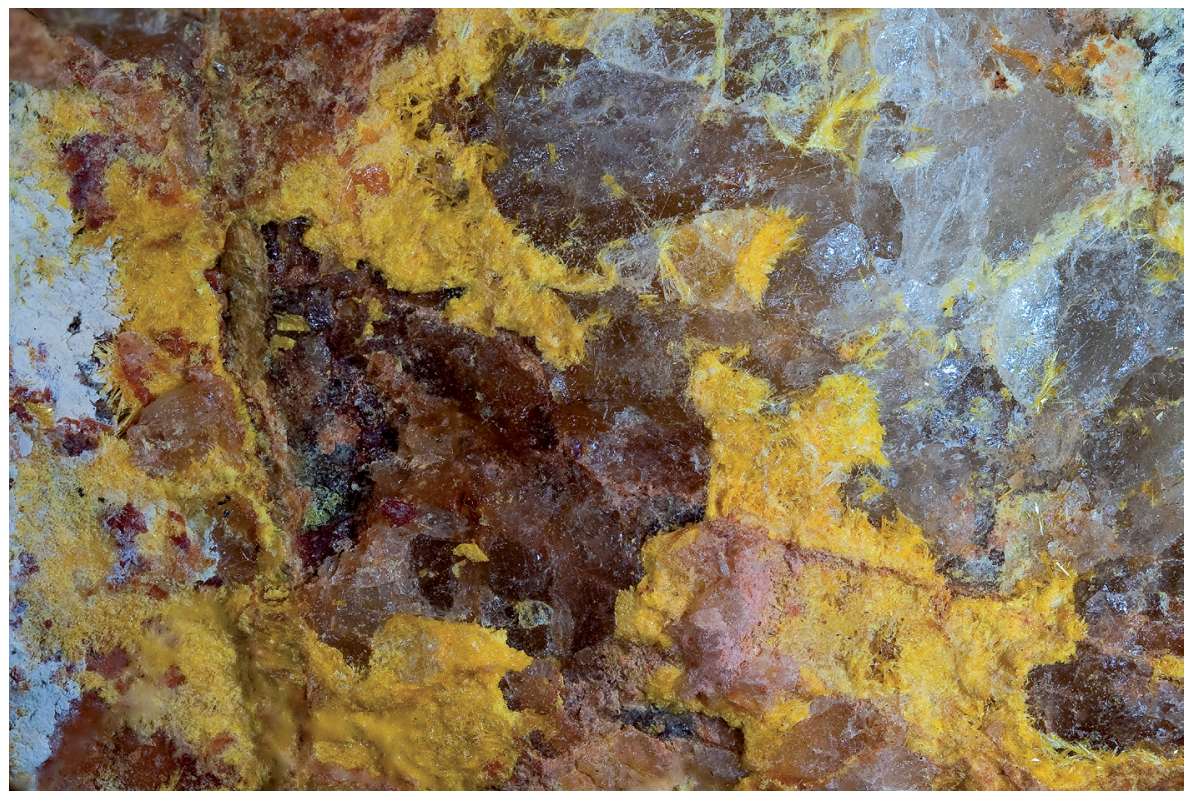

Fig. 1 Crystalline crusts composed of prismatic kamitugaite crystals growing in a fissure. Kobokobo pegmatite, specimen no. RMG13986, Royal Museum for Central Africa, Tervuren, Belgium. Width of photograph is $10 \mathrm{~mm}$ (photo by E. Van Der Meersche).
2017). A spherical absorption correction combined with empirical scaling was applied in Jana2006 (Petříček et al. 2014).

\subsection{Structure solution and refinement}

The structure was solved by the charge-flipping algorithm in SHELXT (Sheldrick 2015). The structure subsequently was refined by the full-matrix least-squares with the Jana2006 program (Petříček et al. 2014) based on $F^{2}$. Atoms that were not found by the initial solution were later located by difference-Fourier syntheses. Uranium, $\mathrm{P}, \mathrm{As}, \mathrm{Al}$ and $\mathrm{Pb}$ atoms, were refined with anisotropic atomic displacement parameters (ADP). Hydrogen atoms could not be located.
Careful inspection of the diffraction frames revealed the presence of additional reflections that result from the split crystal; therefore, it was treated as a twin in the refinement. Metrics of the kamitugaite cell suggest that it could be a twin by reticular merohedry; twin operation by the matrix $(-107 ;-100 ; 0-10)$; however, the twin fraction obtained from the refinement was very low $(\sim 0.007)$ with no impact on refinement. Final cycles converged to $R=0.1074$ and $w R=0.2539$ for 2697 observed reflections with goodness of fit (GOF) of 1.81 (Tab. 1). The relatively low quality of the refinement is mainly due to poorly fitted absorption effects. Several O atoms $(\mathrm{O} 1, \mathrm{O} 2, \mathrm{O} 7, \mathrm{O} 8)$ within the sheet were restrained to have the same displacement parameters, because of the tendency of some of them

Tab. 1 Actinide-bearing minerals discovered from the Kobokobo pegmatite

\begin{tabular}{|c|c|c|c|}
\hline & Chemical formula & Structure determined by & Primary reference \\
\hline \multicolumn{4}{|l|}{$U$ minerals } \\
\hline Kamitugaite & $\mathrm{PbAl}\left[\left(\mathrm{UO}_{2}\right)_{5}\left(\mathrm{PO}_{4}\right)_{3} \mathrm{O}_{2}(\mathrm{OH})_{2}\right]\left(\mathrm{H}_{2} \mathrm{O}\right)_{11.5}$ & this work & Deliens and Piret (1984) \\
\hline Metavanmeersscheite & $\mathrm{U}^{6+}\left(\mathrm{UO}_{2}\right)_{3}\left(\mathrm{PO}_{4}\right)_{2}(\mathrm{OH})_{6}\left(\mathrm{H}_{2} \mathrm{O}\right)_{2}$ & & Piret and Deliens (1982) \\
\hline Moreauite & $\mathrm{Al}_{3}\left(\mathrm{UO}_{2}\right)\left(\mathrm{PO}_{4}\right)_{3}(\mathrm{OH})_{2}\left(\mathrm{H}_{2} \mathrm{O}\right)_{13}$ & & Deliens and Piret (1985a) \\
\hline Mundite & $\mathrm{Al}\left(\mathrm{UO}_{2}\right)_{3}\left(\mathrm{PO}_{4}\right)_{2}(\mathrm{OH})_{3}\left(\mathrm{H}_{2} \mathrm{O}\right)_{5.5}$ & & Deliens and Piret (1981) \\
\hline Phuralumite & $\mathrm{Al}_{2}\left[\left(\mathrm{UO}_{2}\right)_{3}\left(\mathrm{PO}_{4}\right)_{2} \mathrm{O}(\mathrm{OH})\right](\mathrm{OH})_{3} \cdot 9 \mathrm{H}_{2} \mathrm{O}$ & Dal Bo et al. (2017b) & Deliens and Piret (1979a) \\
\hline Ranunculite & $\mathrm{Al}\left(\mathrm{UO}_{2}\right)\left(\mathrm{PO}_{3} \mathrm{OH}\right)(\mathrm{OH})_{3}\left(\mathrm{H}_{2} \mathrm{O}\right)_{4}$ & & Deliens and Piret (1979c) \\
\hline Threadgoldite & $\mathrm{Al}\left(\mathrm{UO}_{2}\right)_{2}\left(\mathrm{PO}_{4}\right)(\mathrm{OH})\left(\mathrm{H}_{2} \mathrm{O}\right)_{8}$ & Khosrawan-Sazedj (1982) & Deliens and Piret (1979b) \\
\hline Triangulite & $\mathrm{Al}_{3}\left(\mathrm{UO}_{2}\right)_{4}\left(\mathrm{PO}_{4}\right)_{4}(\mathrm{OH})_{5}\left(\mathrm{H}_{2} \mathrm{O}\right)_{5}$ & & Deliens and Piret (1982) \\
\hline Upalite & $\mathrm{Al}\left[\left(\mathrm{UO}_{2}\right)_{3}\left(\mathrm{PO}_{4}\right)_{2} \mathrm{O}(\mathrm{OH})\right]\left(\mathrm{H}_{2} \mathrm{O}\right)_{7}$ & Piret and Declercq (1983) & Deliens and Piret (1979a) \\
\hline Vanmeerscheite & $\mathrm{U}^{6+}\left(\mathrm{UO}_{2}\right)_{3}\left(\mathrm{PO}_{4}\right)_{2}(\mathrm{OH})_{6}\left(\mathrm{H}_{2} \mathrm{O}\right)_{4}$ & Piret and Deliens (1982) & Piret and Deliens (1982) \\
\hline Furongite* & $\mathrm{Al}_{4}\left[\left(\mathrm{UO}_{2}\right)_{4}\left(\mathrm{PO}_{4}\right)_{6}\right](\mathrm{OH})_{2}\left(\mathrm{H}_{2} \mathrm{O}\right)_{19.5}$ & Dal Bo et al. (2017a) & Hunan Team (1976) \\
\hline \multicolumn{4}{|l|}{ Th minerals } \\
\hline Althupite & $\operatorname{AlTh}\left(\mathrm{UO}_{2}\right)_{7}\left(\mathrm{PO}_{4}\right)_{4} \mathrm{O}_{2}(\mathrm{OH})_{5}\left(\mathrm{H}_{2} \mathrm{O}\right)_{15}$ & Piret and Deliens (1987) & Piret and Deliens (1987) \\
\hline Eylettersite & $\mathrm{Th}_{0.75} \mathrm{Al}_{3}\left(\mathrm{PO}_{4}\right)_{2}(\mathrm{OH})_{6}$ & & Van Wambeke (1972) \\
\hline
\end{tabular}

*originally described from Hunan province, China; from Kobokobo reported by Deliens and Piret (1985a) 
to have non-positive definite atomic displacement parameters (most probably due to poor absorption correction). Details of the data collection and miscellaneous crystallographic and structure refinement parameters are listed in Tab. 1. Final atom coordinates and displacement parameters are given in Tabs 2 and 3 . Bond-valence sums were calculated by the DIST option in Jana2006 using the parameters given by Burns et al. (1997) and Gagné and Hawthorne (2015). Selected bond distances are given in Tab. 4. The CIF file, also containing a block with the reflections, is deposited at the Journal's webpage $w w w$.jgeosci.org.

\section{Results - crystal structure}

There are five $\mathrm{U}$, three $\mathrm{P} / \mathrm{As}$, one $\mathrm{Pb}$, one $\mathrm{Al}$ and thirty-eight $\mathrm{O}$ sites in the structure of kamitugaite. There are four $U$ sites (U1 to U4), occupied by $\mathrm{U}^{6+}$ and coordinated by seven ligands, and a single U5 site, coordinated by eight ligands in a hexagonal bipyramid. Three tetrahedrally coordinated cation sites are filled dominantly by $\mathrm{P}^{5+}$. However, one site (As1/P1) was found to be occupied predominantly by $\mathrm{As}^{5+}$ over $\mathrm{P}^{5+}$. Interlayer cations, $\mathrm{Al}^{3+}$ and $\mathrm{Pb}^{2+}$, are coordinated by six and nine ligands, respectively.

The $\mathrm{UO}_{7}$ pentagonal bipyramids form dimers by edge-sharing, which in turn share edges with $\mathrm{UO}_{8}$ hexagonal bipyramids resulting in fragments (Fig. 2) of the well-known phosphuranylite topology (Burns 2005). In kamitugaite, however, these fragments are linked by edge-sharing of two $\mathrm{UO}_{7}$ bipyramids, resulting in infinite chains along [010] (Fig. 3). The $\mathrm{O}$ sites shared by two bipyramids are $\mathrm{OH}$ groups (Tab. 3). Adjacent chains of U-polyhedra are connected through corner-sharing (As1/ $\mathrm{P} 1)$ and edge-sharing (P2, P3) tetrahedra, yielding a $\left[\left(\mathrm{UO}_{2}\right)_{5}\left(\mathrm{PO}_{4}\right)_{3} \mathrm{O}_{2}(\mathrm{OH})_{2}\right]^{5-}$ sheet parallel to $\{001\}$ (Fig. 3 ). There are two different intersheet regions in kamitugaite structure, one at $z \sim 0$ and second at $z \sim 0.5$. These two intersheet regions accommodate cations with very different stereochemistries. The first complex involves octahedrally coordinated $\mathrm{Al}^{3+}$ site, in the form of a regular octahedron, by the two $\mathrm{O}$ atoms from the P2 and P3 tetrahedra (within the same sheet) and four $\mathrm{H}_{2} \mathrm{O}$ groups. The second intersheet region features a $\mathrm{Pb}^{2+}$ cation surrounded by nine ligands (Tab. 5), including four $\mathrm{O}_{\text {Uranyl }}$ atoms from adjacent sheets and five $\mathrm{H}_{2} \mathrm{O}$ groups (two of them occupy symmetrically related $\mathrm{O} 38$ sites). The slight asymmetry of the $\mathrm{Pb}^{2+}$ coordination environment suggests that the $6 \mathrm{~s}^{2}$ lone-electron pair can be stereoactive in kamitugaite. There are additional four independent $\mathrm{O}$ sites (O25, O32, O31 and a half-occupied O35) in both intersheet regions occupied by $\mathrm{H}_{2} \mathrm{O}$ that are not linked directly to any metal cation. To sum up, adjacent structure 
Tab. 3 Atom coordinates, occupational and displacement parameters and bond-valence sums (in valence units) for the crystal structure of kamitugaite

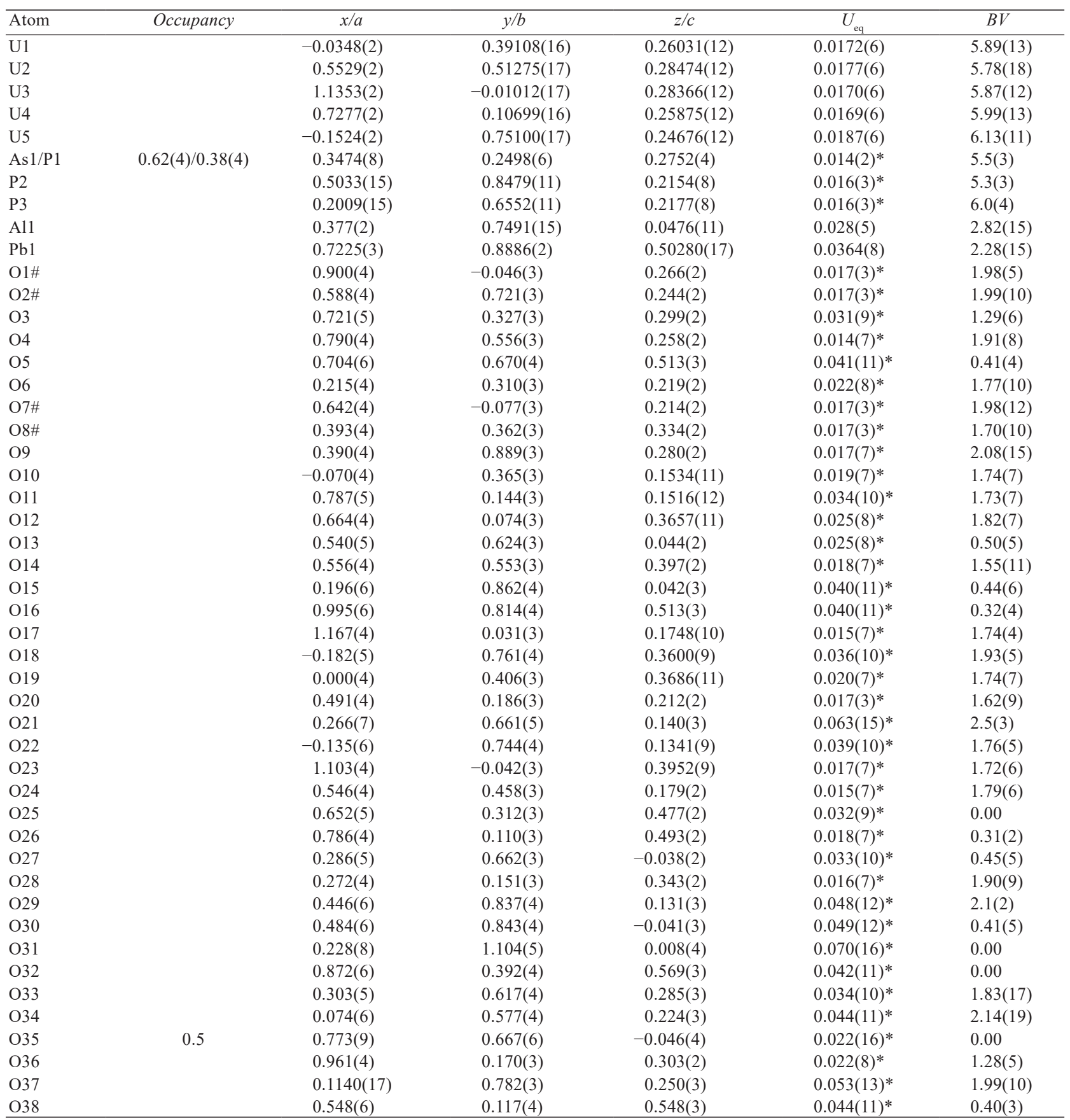

* atoms refined with isotropic displacement parameters; \# atoms restricted to have same displacement parameters;

$B V-$ sum of bond-valences (in valence units)

Tab. 4 Anisotropic displacement parameters for the crystal structure of kamitugaite

\begin{tabular}{|c|c|c|c|c|c|c|}
\hline Atom & $U^{I I}$ & $U^{22}$ & $U^{33}$ & $U^{12}$ & $U^{13}$ & $U^{23}$ \\
\hline U1 & $0.0109(9)$ & $0.0129(9)$ & $0.0284(11)$ & $-0.0037(7)$ & $-0.0028(8)$ & $-0.0007(7)$ \\
\hline $\mathrm{U} 2$ & $0.0117(9)$ & $0.0169(9)$ & $0.0248(10)$ & $-0.0034(7)$ & $-0.0011(8)$ & $-0.0007(7)$ \\
\hline U3 & $0.0106(9)$ & $0.0155(9)$ & $0.0256(10)$ & $-0.0033(7)$ & $-0.0021(8)$ & $-0.0023(7)$ \\
\hline U4 & $0.0131(9)$ & $0.0120(9)$ & $0.0263(11)$ & $-0.0034(7)$ & $-0.0024(8)$ & $-0.0007(7)$ \\
\hline U5 & $0.0131(9)$ & $0.0167(9)$ & $0.0274(11)$ & $-0.0055(7)$ & $-0.0031(8)$ & $-0.0013(8)$ \\
\hline $\mathrm{Pb} 1$ & $0.0359(14)$ & $0.0339(12)$ & $0.0408(14)$ & $-0.0053(10)$ & $-0.0087(11)$ & $-0.0003(10)$ \\
\hline Al1 & $0.034(10)$ & $0.017(7)$ & $0.033(9)$ & $-0.005(7)$ & $-0.005(8)$ & $-0.003(7)$ \\
\hline
\end{tabular}




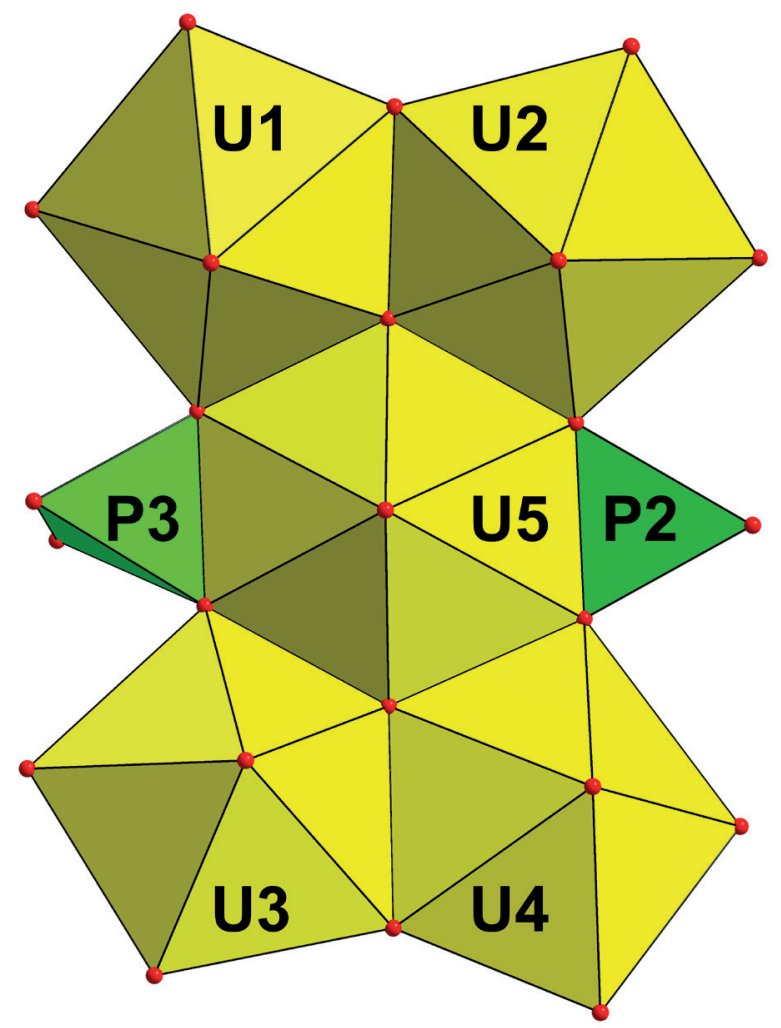

Fig. 2 Fundamental building block in the structural sheet of kamitugaite (U polyhedra yellow, $\mathrm{PO}_{4}$ green).

units are linked either by $\mathrm{Pb}-\mathrm{O}$ bonds (+hydrogen bonds), or through hydrogen bond only (in case of intersheet region with $\mathrm{Al}$ ) (Fig. 4).

The structural formula of kamitugaite obtained from the results of the structure refinement is $\mathrm{Pb}\left(\mathrm{H}_{2} \mathrm{O}\right)_{4}$ $\mathrm{Al}\left(\mathrm{H}_{2} \mathrm{O}\right)_{4}\left[\left(\mathrm{UO}_{2}\right)_{5}\left(\mathrm{PO}_{4}\right)_{2.38}\left(\mathrm{AsO}_{4}\right)_{0.62} \mathrm{O}_{2}(\mathrm{OH})_{2}\right]\left(\mathrm{H}_{2} \mathrm{O}\right)_{3.5}, \mathrm{Z}=2$.

a)

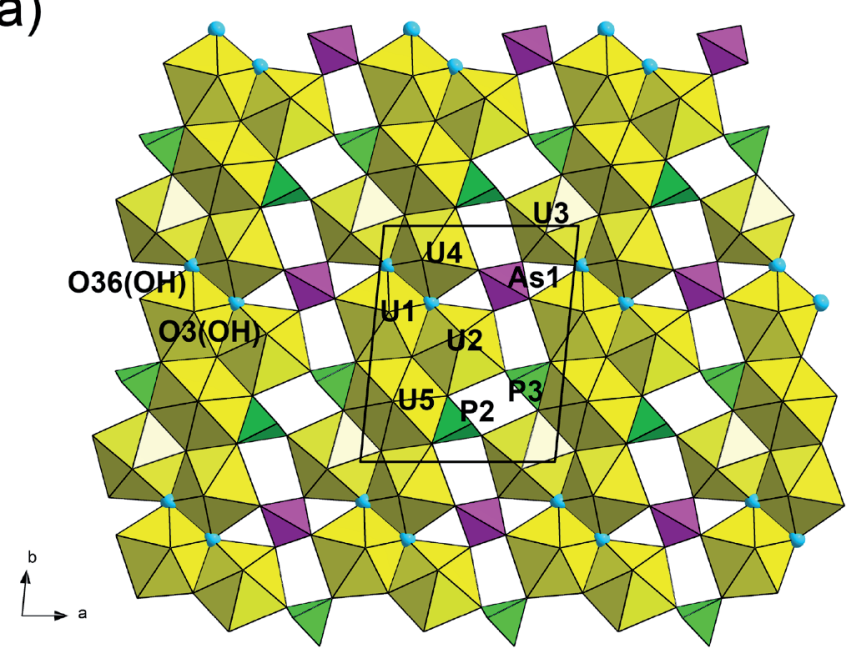

\section{Discussion and conclusions}

\subsection{Sheet topology}

The uranyl-phosphate sheet found in kamitugaite represents a novel topological type with some similarities to phosphuranylite anion topology. The basic module within the sheet is the phosphuranylite-like $\left(\mathrm{UO}_{8}\right)\left(\mathrm{UO}_{7}\right)_{4}\left(\mathrm{TO}_{4}\right)_{2}$ module. However, in kamitugaite there is an additional $T$-site linking adjacent uranyl-phosphate chains together by sharing all vertices. The proportion U:T in kamitugaite is $5: 3$ while in phosphuranylite it is $3: 2$ (within the sheet). This results in the sheet composed of triangles, squares, pentagons and hexagons (TrSqPtHx sheet) of the new topology that has not been observed either in minerals or synthetic compounds (Burns 2005; Lussier et al. 2016); the sheet is characterized by the ring symbol $6^{1} 5^{4} 4^{3} 3^{4}$ (Fig. 4; following Krivovichev 2009).

Both P2 and P3 tetrahedra share three of their vertices with the U-P chains, leaving the third vertex not linked within the sheet (Fig. 3). This may result in the possibility of orientational stereoisomerism within the sheet (Krivovichev 2009, 2010). Although, in kamitugaite the vertices are not free since they are linked to the $\mathrm{Al}$ site.

\subsection{A comparison with the original description}

The unit cell reported in the original paper by Deliens and Piret (1984) describing kamitugaite as a new mineral is very similar to that found by the current single-crystal $\mathrm{X}$-ray study; the only difference is in the unit cell set-

b)

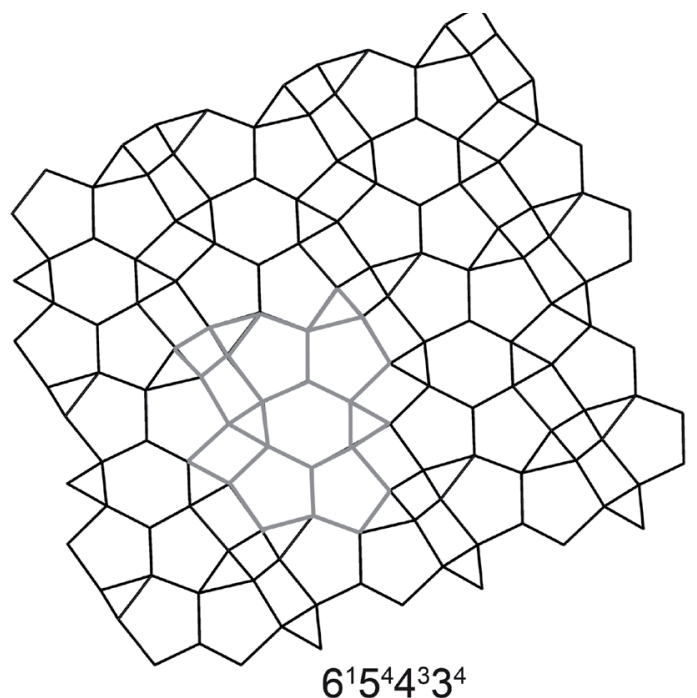

Fig. 3 Structural unit in kamitugaite. a - Uranyl phosphate-arsenate sheet composed of infinite chains built up from phosphuranylite-like fragments that are linked via edge- and vertex-sharing $\mathrm{AsO}_{4}$ and $\mathrm{PO}_{4}$ tetrahedra. The $\mathrm{OH}$ groups are represented by blue spheres. Unit cell edges outlined by black lines. b - Corresponding uranyl-anion topology with the ring symbol (particular part shaded in grey). 
Tab. 5 Selected interatomic distances in the crystal structure of kamitugaite

\begin{tabular}{|c|c|c|c|c|c|}
\hline $\mathrm{U} 1-\mathrm{O} 10$ & $1.783(19)$ & $\mathrm{U} 2-\mathrm{O} 14$ & $1.84(3)$ & U3-O17 & $1.783(18)$ \\
\hline U1-O19 & $1.785(19)$ & $\mathrm{U} 2-\mathrm{O} 24$ & $1.79(3)$ & $\mathrm{U} 3-\mathrm{O} 23$ & $1.802(16)$ \\
\hline $\mathrm{U} 1-\mathrm{O} 3^{\mathrm{i}}$ & $2.41(4)$ & $\mathrm{U} 2-\mathrm{O} 2$ & $2.41(3)$ & U3-O1 & $2.24(4)$ \\
\hline $\mathrm{U} 1-\mathrm{O} 4^{\mathrm{i}}$ & $2.28(3)$ & $\mathrm{U} 2-\mathrm{O} 3$ & $2.43(4)$ & $\mathrm{U} 3-\mathrm{O} 9^{\mathrm{ii}}$ & $2.45(3)$ \\
\hline U1-O6 & $2.38(3)$ & $\mathrm{U} 2-\mathrm{O} 4$ & $2.25(4)$ & $\mathrm{U} 3-\mathrm{O} 28^{\mathrm{iii}}$ & $2.48(4)$ \\
\hline U1-O34 & $2.39(5)$ & $\mathrm{U} 2-\mathrm{O} 8$ & $2.39(4)$ & U3-O36 & $2.40(3)$ \\
\hline $\mathrm{U} 1-\mathrm{O} 36^{\mathrm{i}}$ & $2.51(3)$ & $\mathrm{U} 2-\mathrm{O} 33$ & $2.42(4)$ & $\mathrm{U} 3-\mathrm{O} 37^{\mathrm{ii}}$ & $2.37(3)$ \\
\hline$<\mathrm{U} 1-\mathrm{O}_{U r}>$ & 1.78 & $<\mathrm{U} 2-\mathrm{O}_{U r}>$ & 1.82 & $<\mathrm{U} 3-\mathrm{O}_{U r}>$ & 1.79 \\
\hline$<\mathrm{U} 1-\mathrm{O}_{\mathrm{eq}}>$ & 2.39 & $<\mathrm{U} 2-\mathrm{O}_{\mathrm{eq}}>$ & 2.38 & $<\mathrm{U} 3-\mathrm{O}_{\mathrm{eq}}>$ & 2.39 \\
\hline U4-O11 & $1.79(2)$ & U5-O18 & $1.792(15)$ & & \\
\hline U4-O12 & $1.793(19)$ & U5-O22 & $1.779(14)$ & & \\
\hline U4-O1 & $2.19(3)$ & $\mathrm{U} 5-\mathrm{O} 1^{\mathrm{iv}}$ & $2.34(3)$ & & \\
\hline U4-O3 & $2.49(3)$ & $\mathrm{U} 5-\mathrm{O} 2^{\mathrm{i}}$ & $2.40(4)$ & & \\
\hline U4-O7 & $2.36(3)$ & $\mathrm{U} 5-\mathrm{O} 4^{\mathrm{i}}$ & $2.25(3)$ & & \\
\hline U4-O20 & $2.40(4)$ & $\mathrm{U} 5-\mathrm{O} 7^{\mathrm{iv}}$ & $2.59(3)$ & & \\
\hline U4-O36 & $2.44(4)$ & U5-O34 & $2.66(5)$ & & \\
\hline$<\mathrm{U} 4-\mathrm{O}_{U r}>$ & 1.79 & U5-O37 & $2.47(2)$ & & \\
\hline$<\mathrm{U} 4-\mathrm{O}_{\text {eq }}>$ & 2.38 & $\begin{array}{l}<\mathrm{U} 5-\mathrm{O}_{U r}> \\
<\mathrm{U} 5-\mathrm{O}_{\mathrm{eq}}>\end{array}$ & $\begin{array}{l}1.79 \\
2.45\end{array}$ & & \\
\hline As1-O6 & $1.63(4)$ & $\mathrm{P} 2-\mathrm{O} 2$ & $1.60(3)$ & $\mathrm{P} 3-\mathrm{O} 21$ & $1.32(5)$ \\
\hline As1-O8 & $1.65(3)$ & $\mathrm{P} 2-\mathrm{O}^{\mathrm{v}} \mathrm{v}$ & $1.57(4)$ & P3-O33 & $1.50(5)$ \\
\hline As1-O20 & $1.67(3)$ & P2-O9 & $1.42(3)$ & P3-O34 & $1.49(5)$ \\
\hline As1-O28 & $1.67(3)$ & $\mathrm{P} 2-\mathrm{O} 29$ & $1.48(5)$ & P3-O37 & $1.59(3)$ \\
\hline$<$ As1-O > & 1.66 & $<\mathrm{P} 2-\mathrm{O}>$ & 1.52 & $<\mathrm{P} 3-\mathrm{O}>$ & 1.48 \\
\hline Al1-O13 & $1.90(4)$ & $\mathrm{Pb} 1-\mathrm{O} 5$ & $2.42(4)$ & & \\
\hline A11-O15 & $1.96(5)$ & $\mathrm{Pb} 1-\mathrm{O} 12^{\mathrm{v}}$ & $3.00(3)$ & & \\
\hline $\mathrm{A} 11-\mathrm{O} 21$ & $1.99(6)$ & $\mathrm{Pb} 1-\mathrm{O} 16$ & $2.53(5)$ & & \\
\hline $\mathrm{A} 11-\mathrm{O} 27$ & $1.95(4)$ & $\mathrm{Pb} 1-\mathrm{O} 18^{\mathrm{iii}}$ & 2.71(3) & & \\
\hline A11-O29 & $1.82(5)$ & $\mathrm{Pb} 1-\mathrm{O} 23^{\mathrm{vi}}$ & $2.98(3)$ & & \\
\hline $\mathrm{A} 11-\mathrm{O} 30$ & $1.98(5)$ & $\mathrm{Pb} 1-\mathrm{O} 26^{\mathrm{v}}$ & $2.55(3)$ & & \\
\hline \multirow[t]{4}{*}{$<\mathrm{Al1}-\mathrm{O}>$} & 1.93 & $\mathrm{~Pb} 1-\mathrm{O} 28^{\text {vii }}$ & $2.48(3)$ & & \\
\hline & & $\mathrm{Pb} 1-\mathrm{O} 38^{v}$ & $2.88(4)$ & & \\
\hline & & $\mathrm{Pb} 1-\mathrm{O} 38^{\mathrm{vii}}$ & $2.64(5)$ & & \\
\hline & & $<\mathrm{Pb} 1-\mathrm{O}>$ & 2.69 & & \\
\hline
\end{tabular}

Symmetry codes: (i) $x-1, y, z$; (ii) $x+1, y-1, z$; (iii) $x+1, y, z$; (iv) $x-1, y+1, z$; (v) $x, y+1, z$; (vi) $-x+2,-y+1,-z+1$; (vii) $-x+1,-y+1,-z+1$; (viii) $-x+1,-y+1,-z$; (ix) $x, y-1, z$; (x) $-x,-y+1,-z$; (xi) $-x+1,-y,-z+1$; (xii) $-x,-y+2,-z$; (xiii) $-x+2,-y,-z+1$; (xiv) $-x+1,-y+2,-z$.

ting. The chemical composition given in the original description differs in the total amount of $\mathrm{H}_{2} \mathrm{O}$, giving $14 \mathrm{H}_{2} \mathrm{O}\left(=9.5 \mathrm{H}_{2} \mathrm{O}+9 \mathrm{OH}\right)$; however, $\mathrm{H}_{2} \mathrm{O}$ content was not determined directly, but by difference. The current structure study reliably indicates $11.5 \mathrm{H}_{2} \mathrm{O}+2 \mathrm{OH}$ in total (including one half-occupied $\mathrm{H}_{2} \mathrm{O}$ site). Notably, kamitugaite was described as an As-containing (Deliens and Piret 1984, 1985b) species. As indicated by the current structure study, As is predominant at one of the tetrahedral sites only (As1 site; with the mean bond length of $1.66 \AA$ ). Based on the site-scattering refinement, the As content is equal to $0.64 \mathrm{As} p f u$, which is even higher than reported in the original paper.

\subsection{The occurrence of kamitugaite}

Kamitugaite has been reliably confirmed only from the type locality, the Kobokobo pegmatite. At Ko- bokobo, kamitugaite is one of the two minerals that contain essential $\mathrm{Pb}$, the other being dumontite, $\mathrm{Pb}_{2}\left(\mathrm{UO}_{2}\right)_{3}\left(\mathrm{PO}_{4}\right)_{2}(\mathrm{OH})_{4} \cdot 3 \mathrm{H}_{2} \mathrm{O}$. The unique combination of elements in kamitugaite most probably contributes to its scarcity; no other known mineral contains essential $\mathrm{Pb}, \mathrm{Al}$ and $\mathrm{U}$, let alone $\mathrm{P}$ and As. The source of the $\mathrm{Pb}$ is unknown; no primary $\mathrm{Pb}$-bearing minerals have been observed in the Kobokobo pegmatite. Most likely radiogenic lead, otherwise rather immobile, was mobilized from weathered uraninite by alteration solutions.

Acknowledgements. We thank Florias Mees (Royal Museum for Central Africa, Tervuren, Belgium) for his kind cooperation in the sample preparation and for valuable comments. Eddy Van Der Meersche (Gent, Belgium) is acknowledged for microphotography. Comments by Sergey Krivovichev and Anthony Kampf helped improving quality of the earlier version of the manuscript. This re- 
Fig. 4 Crystal structure of kamitugaite viewed down [100]. Uranyl phosphatearsenate sheets alternate two types of intersheet region: those occupied by $\mathrm{Pb}^{2+}$ cation (in plum color, balland-stick model) and molecular $\mathrm{H}_{2} \mathrm{O}$, and those occupied by $\mathrm{Al}^{3+}$-octahedra (cyan) and a molecular $\mathrm{H}_{2} \mathrm{O}$. Water molecules that are not linked directly to metal cations are labeled. Other colors follow the scheme from Fig. 3. Unit-cell edges outlined by black lines.

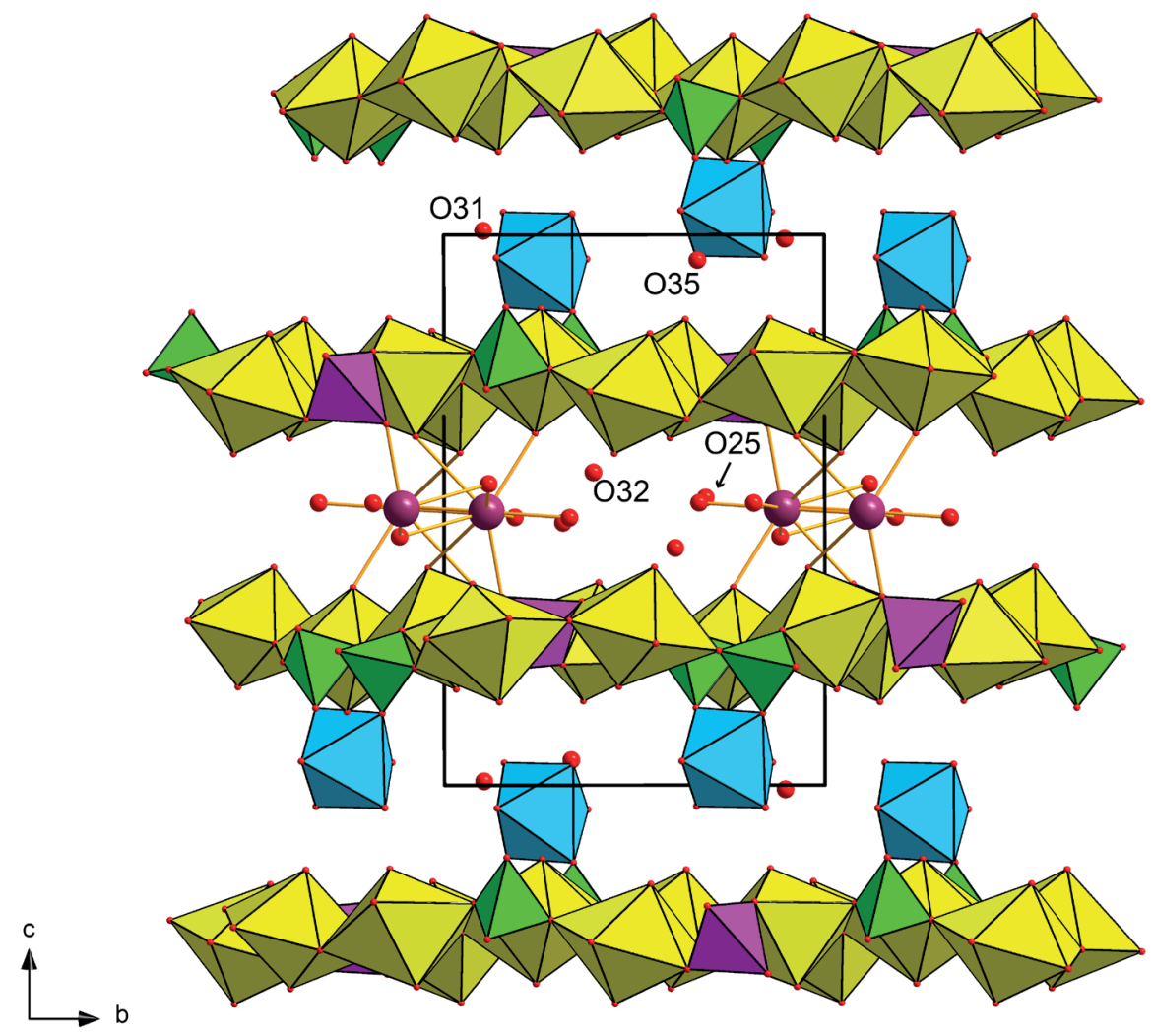

search was supported through the project No. 17-09161S of the Grant agency of the Czech Republic.

Electronic supplementary material. Supplementary crystallographic data for this paper (a CIF file) are available online at the Journal website (http://dx.doi.org/10.3190/ jgeosci.246).

\section{References}

BURNs PC (2005) $\mathrm{U}^{6+}$ minerals and inorganic compounds: insights into an expanded structural hierarchy of crystal structures. Canad Mineral 43: 1839-1894

Burns PC, Ewing RC, Hawthorne FC (1997) The crystal chemistry of hexavalent uranium: polyhedron geometries, bond-valence parameters, and polymerization of polyhedra. Canad Mineral 35: 1551-1570

Dal Bo F, Hatért F, PhilipPo S (2017a) A new uranyl phosphate sheet in the crystal structure of furongite. Eur J Mineral 29: 517-527

Dal Bo F, Hatért F, Philippo S (2017b) New crystallographic data and formula revision of phuralumite, $\mathrm{Al}_{2}\left[\left(\mathrm{UO}_{2}\right)_{3}\left(\mathrm{PO}_{4}\right)_{2} \mathrm{O}(\mathrm{OH})\right](\mathrm{OH})_{3}\left(\mathrm{H}_{2} \mathrm{O}\right)_{9}$. J Geosci 62: $87-95$

Deliens M, Piret P (1979a) Les phosphates d'uranyle et d'aluminium de Kobokobo. II. La phuralumite $\mathrm{Al}_{2}\left(\mathrm{UO}_{2}\right)_{3}\left(\mathrm{PO}_{4}\right)_{2}(\mathrm{OH})_{6} \cdot 10 \mathrm{H}_{2} \mathrm{O}$ et l'upalite
$\mathrm{Al}\left(\mathrm{UO}_{2}\right)_{3}\left(\mathrm{PO}_{4}\right)_{2}(\mathrm{OH})_{3}$, nouveaux minéraux. Bull Minéral 102: 333-337

Deliens M, Piret P (1979b) Les phosphates d'uranyle et d'aluminium de Kobokobo. IV. La threadgoldite, $\mathrm{Al}\left(\mathrm{UO}_{2}\right)_{2}\left(\mathrm{PO}_{4}\right)_{2}(\mathrm{OH}) \cdot 8 \mathrm{H}_{2} \mathrm{O}$, nouveau minéral. Bull Minéral 102: 338-341

Deliens M, Piret P (1979c) Ranunculite, $\mathrm{AlH}\left(\mathrm{UO}_{2}\right)\left(\mathrm{PO}_{4}\right)$ $(\mathrm{OH})_{3} \cdot 4 \mathrm{H}_{2} \mathrm{O}$, a new mineral. Mineral Mag 43: 321-323

Deliens M, Piret P (1981) Les phosphates d'uranyle et d'aluminium de Kobokobo. V. La mundite, nouveau minéral. Bull Minéral 104: 669-671

Deliens M, Piret P (1982) Les phosphates d'uranyle et d'aluminium de Kobokobo. VI. La triangulite, $\mathrm{Al} 3\left(\mathrm{UO}_{2} \cdot \mathrm{PO}_{4}\right)_{4}(\mathrm{OH})_{5} \cdot 5 \mathrm{H}_{2} \mathrm{O}$, nouveau minéral. Bull Minéral 105: 611-614

Deliens M, Piret P (1984) La kamitugaïte, $\mathrm{PbAl}\left(\mathrm{UO}_{2}\right)_{5}$ $\left[(\mathrm{P}, \mathrm{As}) \mathrm{O}_{4}\right]_{2}(\mathrm{OH})_{9} \cdot 9,5 \mathrm{H}_{2} \mathrm{O}$, nouveau minéral de Kobokobo, Kivu, Zaïre. Bull Minéral 107: 15-19

Deliens M, Piret P (1985a) Les phosphates d'uranyle et d'aluminium de Kobokobo. VII. La moreauïte, $\mathrm{Al}_{3} \mathrm{UO}_{2}\left(\mathrm{PO}_{4}\right)_{3}(\mathrm{OH})_{2} \cdot 13 \mathrm{H}_{2} \mathrm{O}$, nouveau minéral. Bull Minéral 108: 9-13

Deliens M, Piret P (1985b) Les minéralisations secondaires d'uranium associées à la pegmatite de Kobokobo, Kivu, Zaire. Revue des phosphates d'uranium du groupe structural de la phosphuranylite-dumontite. Rapp a Dép Géol Minéral Mus roy Afr cent, Ann 1983-1984, pp 81-86 
FINCH RJ, MuraKami T (1999) Systematics and paragenesis of uranium minerals. In: BuRNs PC, FINCH RJ (eds) Uranium: Mineralogy, Geochemistry and the Environment. Mineralogical Society of America and Geochemical Society Reviews in Mineralogy 38: pp 91-180

Gagné OC, Hawthorne FC (2015) Comprehensive derivation of bond-valence parameters for ion pairs involving oxygen. Acta Crystallogr B71: 562-578

GöB S, GüHring J-E, BAU M, MARKL G (2013) Remobilization of $U$ and REE and the formation of secondary minerals in oxidized U deposits. Amer Miner 98: 530-548

Hunan Team (1976) A new mineral discovered in China. Furongite $\mathrm{Al}_{2}\left(\mathrm{UO}_{2}\right)\left(\mathrm{PO}_{4}\right)_{2}(\mathrm{OH})_{2} \cdot 8 \mathrm{H}_{2} \mathrm{O}$. Acta Geol Sin 2: 203-204

KHOSRAWAN-SAZEDJ F (1982) On the space group of threadgoldite. Tschermaks Mineral Petrogr Mitt 30: 111-115

KrivovicheV SV (2009) Graph theory applied to lowdimensional structural units in inorganic oxysalts. In: KRIVOVICHEV SV (ed) Structural Crystallography of Inorganic Oxysalts. IUCr Monographs on Crystallography 22. Oxford University Press, Oxford, pp 6-93

KrIVOVICHEV SV (2010) Actinyl compounds with hexavalent elements ( $\mathrm{S}, \mathrm{Cr}, \mathrm{Se}, \mathrm{Mo}$ ) - structural diversity, nanoscale chemistry, and cellular automata modeling. Eur J Inorg Chem 18: 2594-2603

KrIVovichev SV, PLÁŠIL J (2013) Mineralogy and crystallography of uranium. In: BuRns PC, SigMON GE (eds) Uranium: From Cradle to Grave. Mineralogical Association of Canada Short Courses 43: pp 15-119

Lussier AJ, Lopez RAK, Burns PC (2016) A revised and expanded structure hierarchy of natural and synthetic hexavalent uranium compounds. Canad Mineral 54: 177-283

PetříčEK V, DušEK M, PALATINus L (2014) Crystallographic computing system Jana2006: general features. Z Kristallogr 229: 345-352

Piret P, DeclercQ J-P (1983) Structure cristalline de l'upalite $\mathrm{Al}\left[\left(\mathrm{UO}_{2}\right)_{3} \mathrm{O}(\mathrm{OH})\left(\mathrm{PO}_{4}\right)_{2}\right] \cdot 7 \mathrm{H}_{2} \mathrm{O}$. Un exemple de macle mimétique. Bull Minéral 106: 383-389

Piret P, Deliens M (1982) La vanmeerscheite $\mathrm{U}\left(\mathrm{UO}_{2}\right)_{3}\left(\mathrm{PO}_{4}\right)_{2}(\mathrm{OH})_{6} \cdot 4\left(\mathrm{H}_{2} \mathrm{O}\right)$ et la méta-vanmeerscheite $\mathrm{U}\left(\mathrm{UO}_{2}\right)_{3}\left(\mathrm{PO}_{4}\right)_{2}(\mathrm{OH})_{6} \cdot 2\left(\mathrm{H}_{2} \mathrm{O}\right)$, nouveaux minéraux. Bull Minéral 105: 125-128

Piret P, Deliens M (1987) Les phosphates d'uranyle et d'aluminium de Kobokobo IX. L'althupite $\mathrm{AlTh}\left(\mathrm{UO}_{2}\right)$ $\left[\left(\mathrm{UO}_{2}\right)_{3} \mathrm{O}(\mathrm{OH})\left(\mathrm{PO}_{4}\right)_{2}\right]_{2}(\mathrm{OH})_{3} \cdot 15 \mathrm{H}_{2} \mathrm{O}$, nouveau minéral; propriétés et structure cristalline. Bull Minéral 110: 65-72

Rigaku (2017) CrysAlis CCD and CrysAlis RED. RigakuOxford Diffraction Ltd, Yarnton, Oxfordshire, UK

SAFiannikoff A, VAn WAmbeKe L (1967) La pegmatite radioactive à béryl de Kobokobo et les autres venues pegmatitiques et filoniennes de la région de Kamituga Kivu - Rép. du Congo. Miner Depos 2: 119-130

SHELDRICK GM (2015) SHELXT - integrated space-group and crystal-structure determination. Acta Crystallogr A71: 3-8

VAN WAMBEKE L (1972) Eylettersite, un nouveau phosphate de thorium appartenant à la série de la crandallite. Bull Soc franc Minéral Cristallogr 95: 98-105

VAN WAMBEKE L (1987) La minéralogie de la pegmatite de Kobokobo, Kivu, Zaïre. Bull Soc belge Géol 96: 137-142 